\title{
SEASONAL TRENDS OF CLIMATE IN THE WET ZONE AND DRY ZONE OF SRI LANKA
}

\author{
JMSB Jayasundara \\ Department of Social Science, Sabaragamuva University of Sri Lanka, Belihuloya
}

Climatic change is an important factor especially in view of current global warming scenarios. Study of climatic changes in Sri Lanka is relevant, particularly, as any changes in the seasonality of rainfall can affect the country's agricultural productivity. It is also important in selecting species for forestry. Hence, the present study attempis to separately ascertain whether there have been changes in seasonal rainfall and temperature ir the 'dry' and 'wet' zones during the 18701999.

As there are no cyclic changes or linear trends observed during the study period, it was divided into four sub-periods: 1870-1909, 1910-1939, 1940-1969 and 1970-1999. Simple regression coefficients were calculated for those sub-periods, considering the year as the independent variable and temperature and rainfall respectively as the dependent variables. Dry zone rainfall and temperature were estimated by averaging the amounts recorded in the meteorological stations of Puttalam, Anuradhapura, Trincomalee and Hambantota. Similarly, wet zone rainfall and temperature were estimated by averaging the amounts recorded in the meteorological stations of Galle, Ratnapura, Nuwara Eliya and Kandy. Averaging the data from different locations reduces measurement errors and fluctuations. Moreover, as monthly data do not necessarily related to seasonality, only typical months for each of the four seasons were selected and the data were averaged for the respective seasons: Southwest monsoon season was represented buy the average of June and July data. Northeast monsoon was represented by the average of December and January data. Likewise the first and second inter-monsoons were represented by April and October data.

The analyses reveal the following trends: A decrease of rainfall during both monsoons and an increase of rainfall in the two inter-monsoons. As for temperature there has been a slight increase all over the island (with the exception of a sl ght decrease in the dry zone in the 19101939 period.)

The first period (1870-1909) is a wetting period indicating a remarkable increase of rainfall all over the island, due to an increase in the rainfall in both inter-monsoon seasons. However, the increase is higher in the dry zone. The second (1910-939) appears a drying and cooling period with a decrease of rainfall in both monsoons as well as in the second inter-monsoon. This period was also a cooling episode for the dry zone. The thitc period (1940-1969had a wetting trend in the dry zone with a drying trend in the wet zone. This contrast was remarkable in three seasons except the first inter-monsoon. The fourth period (1970-1999) was a recovering period with a wetting trend in the wet zone and a drying trend in the dry zone. 